\title{
Platonic Allegory in Henry James's The Portrait of a Lady
}

\author{
Yesim Sultan Yasar \\ Süleyman Demirel University, Isparta, Turkey \\ E-mail: yesimsultan.yasar@gmail.com
}

Beture Memmedova

Süleyman Demirel University, Isparta, Turkey

E-mail: azerbayca@hotmail.com

\section{Doi:10.5901/ajis.2012.v2n4p283}

\section{Abstract:}

Plato's famous allegory was employed while analyzing a number of famous literary pieces like Gulliver's Travels, Wings, The Man Who Lived Underground, and The Bluest Eye. Though Henry James's masterpiece The Portrait of a Lady is not mentioned among these novels written by different writers in different periods, I will try to show that the allegory is an apt tool when analyzing Isabel Archer's character, the protagonist of the novel. Just as the prisoners are able to see only the shadows reflected on the wall, so does Isabel see the shadows of real life. She faces up the realities of life step by step. She is like Plato's prisoners who are suddenly released from their bondage and "pained and dazzled and unable to see the things whose shadows they'd seen before." It is not surprising that each step takes her to suffering and frustration, and it is only through experience that she becomes aware of the truth. However, because of her strong sense of duty and dignity, she does not get rid of her chains completely.

Key Words: The Allegory of Plato, The Portrait of a Lady, Isabel Archer

\begin{abstract}
All that meets the bodily sense I deem
Symbolical, one mighty alphabet

To infant minds; and we in this low world

Placed with our backs to bright reality,

That we might learn with young unwounded ken

The substance from the shadow.
\end{abstract}

\section{S. Coleridge. The Statesman's Manual}

(The Destiny of Nations, 2012)

The Platonic Allegory of the Cave is a narration used by the Greek philosopher Plato in his famous work The Republic. Plato tells us a didactic story where certain people are thought as being imprisoned in a cave and have a certain amount of light. Plato's aim in this amazing work is to show what would happen if those people were taken out of that cave and see the Divine Light of the Sun and thus 'true' reality. In other words, his aim is to show what would really happen if one became aware of the real state of things. The Allegory of Cave, found in the seventh book of The Republic, has been interpreted and used in a number of fields.

In this work, Socrates asks Glaucon, another Greek thinker, to imagine a cave-like place;

Imagine human beings living in an underground, cave-like dwelling, with an entrance a long way up, which is both open to light and as wide as the cave itself. They've been there since childhood, fixed in the same place, with their necks and legs fettered, able to see only in front of them, because their bonds prevent them from turning their heads around. Light is provided by a fire burning far above and streching between them and the 
fire. Imagine that along this path a low wall has been built, like the screen in front of puppeteers above which they show their puppets. ${ }^{1}$ (Cohen et al., 2005, 514 a-b)

Socrates is wondering whether these prisoners are able to see one another "besides the shadows that the fire casts on the wall in front of them?"

In this paper, we will attempt to apply the Allegory to Isabel's situation in the novel The Portrait of a Lady by Henry James. The novel, which can be called an education novel, once again proves the importance of knowledge and experience in order to be able to find the right way in life.

Unlike those in the cave, Isabel is not afraid of change. On the contrary, the book starts with her quest for freedom.

In the opening scene of The Portrait of a Lady we are given the aura of a tea ceremony in the middle of a beautiful summer day.

Part of the afternoon had waned, but much of it was left, and what was left was of the finest and rarest quality. Real dusk would not arrive for many hours; but the flood of summer light had begun to ebb, the air had grown mellow, the shadows were long upon the smooth, dense turf. They lengthened slowly, however, and the scene expressed that sense of leisure still to come which is perhaps the chief source of one's enjoyment of such a scene at such an hour (James, 2011, 21).

The "shadow" and the darkness following it, pursue Isabel throughout the novel. Even before her marriage to Gilbert Osmond, Isabel was in darkness. The quest for her independence has not been entirely enlightened towards the end of the fifty-five-chapter novel. She faces up the realities step by step. Each step takes her to suffering and frustration, and through suffering that she encounters the truth. Nothing would be powerful and effective enough to persuade her to accept other people's common sense. She has to take the risk herself because a slight amount of light would not be clear enough for her vision and lack of her knowledge will lead her to disaster.

In chapter six, the narrator presents to us Isabel who is far from being a voracious reader and her reputation as a "prodigy of learning" (James, 2011, 75) has been spread by her paternal aunt Mrs. Varian. Henry James is openly ironic while assessing the latter's reading abilities:

Her impression with regard to Isabel's labours was quite illusory; the girl had never attempted to write a book and had no desire for the laurels of authorship. She had no talent for expression and too little of the consciousness of genius; she only had a general idea that people were right when they treated her as if she were rather superior (James, 2011:76)

The narrator warns us implicitly not to trust someone whose acquaintance "with literature was confined to the New York Interviewer". (ibid: 76) This is the life she has always known, she would neither understand nor appreciate anything else.

She was looking at everything, with an eye that denoted clear perception-at her companion, at the two dogs, at the two gentlemen under the trees, at the beautiful scene that surrounded her. (James, 2011: 35)

For Isabel, who is looking for change, Gardencourt is a brighter place than Boston; Italy is a better place than England. Ralph, Henrietta, and Countess Gemini are torches for Isabel's vision to reality. They are like the fire giving light to the objects reflected on the wall.

Ralph does his best to fulfil his duty as a fire (light) for Isabel.Ralph resembles Isabel to a ship in her quest for freedom. 
"She's entirely independent of me; I can exercise very little influence upon her life. But I should like to do something for her."

'What should you like to do?'

'I should like to put a little wind in her sails.'

'What do you mean by that?'

"I should like to put it into her power to do some of the things she wants. She wants to see the world for instance. I should like to put money in her purse"(James, 2011: 235)

'You're too passive then. You had better stir yourself and be careful. Isabel's changing every day; she's drifting away-right out to sea. I've watched her and I can see it. She's not the bright American girl she was. She's taking different views, a different colour, and turning away from her old ideals (James, 2011, 161).

'Aren't you perhaps a little too much in a hurry?' Ralph enquired. 'Don't you think you ought to give her more of a chance in poor old England?'

'A chance to ruin her bright young life? One's never too much in a hurry to save a precious human creature from drowning.'(James, 2011, 164).

However, Isabel has to experience the harsh reality of life on her own. The dialogue, which takes place after Isabel's marriage to Osmond, is suggestive of Isabel's ignorance;

'You were the last person I expected to see caught.'

'I don't know why you call it caught.'

'Because you're going to be put into a cage.'

'If I like my cage, that needn't trouble you,'she answered.

'That's what I wonder at; that's what I've been thinking of.'

'If you had been on your guard, however,' Isabel asked, 'what would you have done?'

'I should have said 'Wait a little longer.'

'Wait for what?'

'Well, for a little more light,' said Ralph with rather an absurd smile, while his hands found their way into his pockets.

'Where should my light have come from? From you?'

'I might have struck a spark or two’ (425, 426, emphasis added).(James, 2011, pp. 425-426)

In the Republic Socrates tells us how these prisoners will react if they were to look directly at the fires. They can only see flickers of - or, more importantly, how they would respond if they were ever brought out of the cave into the world. The allegory indeed deals with man's condition in the world, the power of knowledge and truth, and how easy it is for humans to become blinded by their own immediate limitations. In our case Isabel is not wholly aware of the harsh reality of the world. Before being taken to the Old World, namely England - Gardencourt, she deeply contemplates on the effects of how she - herself, would react to the changes of her routine life;

Whether she felt grand or no, she at any rate felt different, felt as if something had happened to her. Left to herself for the evening she sat a while under the lamp, her hands empty, her usual avocations unheeded. Then she rose and moved about the room, and from one room to another, preferring the places where the vague lamplight expired. She was restless and even agitated; at moments she trembled a little. The importance of what had happened was out of proportion to its appearance; there had really been a change in her life. What it would bring with it was as yet extremely indefinite; but Isabel was in a situation that gave a value to any change. She had a desire to leave the past behind her and, as she said to herself, to begin afresh. This desire indeed was not a birth of the present occasion; it was as familiar as the sound of the rain upon the window and it had led to her beginning afresh a great many times. She closed her eyes as she sat in one of the dusky corners of the quiet parlour; but it was not with a desire for dozing forgetfulness. It was on the contrary because she felt too wide-eyed and wished to check the sense of seeing too many things at once. (James, 2011, pp. 53-54)

One of her steps towards reality is with the light that Mrs. Touchett sheds on her. She is to take Isabel to Europe to buy some clothes and let her see the world. If a light was not given to her, then she would have 
only perceived the world by watching shadows on the wall in her native town. She would not realize that there is more to be seen or known, and thus she will have a passive and disinterested kind of life.
... what do you mean to do with her?'
'I mean to take her to Paris. I mean to get her clothing.'
'Ah yes, that's of course. But independently of that?'
'I shall invite her to spend the autumn with me in Florence.'
'You don't rise above detail, dear mother,' said Ralph. 'I should like to know what you mean to do with her in a general way.'
'My duty!' Mrs. Touchett declared. 'I suppose you pity her very much,' she added.
'No, I don't think I pity her. She doesn't strike me as inviting compassion. I think I envy her. Before being sure, however, give me a hint of where you see your duty.'
'In showing her four European countries-1 shall leave her the choice of two of them-and in giving her the opportunity of perfecting herself [...] (James, 2011, pp. 65-66)

Socrates next describes what would occur if the chained man were suddenly released from his bondage and let out into the world.

[...] he'd be pained and dazzled and unable to see the things whose shadows he'd seen before [...] he'd be at a loss [...] (Cohen et al., 2005, p.515 d)

Unlike Plato's prisoner, our heroine of The Portrait is not afraid of suffering. The narrator describes Isabel in terms reminiscent of famous Rumi, "She would be what she appeared, and she would appear what she was" (James, 2011, p.77). She would, in time, take the risk of going out of that cave and wouldn't be taken in by the reflections. So, in contrast to Socrates' description, Isabel shows great courage before the unexpected: 'I'm not afraid, you know,' she said (James, p.73).

Truth-seekers would come to understand the limitations of their previous existence, and would question the deceptions of their former lives. A few would embrace the sun and the "true life," and would therefore have a far better understanding of truth, knowledge, and wisdom. Many would also want to return to the cave to free the others in bondage. They would be puzzled when people, still in the cave, would not believe the "enlightened" truth bearer. Ralph as a truth-seeker tries to dissuade Isabel from marrying Osmond, but fails. For Socrates (Plato), the prisoner is expected to return to the cave and live among his former prisoners as someone who can see better than all the rest, someone who is now able to govern truth and goodness. Just as the prisoner fails to convince them of a better life, so does Ralph in convincing Isabel to see reality.

Isabel herself is a truth seeker, but "truth" must be experienced rather than told because language fails to convey belief. This is one of the sustained themes of Plato's works. "Faith can't be given to other people, but must be experienced to be known", states Plato. Isabel's never-ending questions to Mr. Touchett about different aspects of English life suggest her intellectual curiosity. Isabel is wondering whether Mr. Touchet's notions are like those in the books she read. Mr. Touchett's answer is realistic:

'The books?' He once said; 'well, I don't know much about the books. You must ask Ralph about that. I have always ascertained for myself - got my information in the natural form. I never asked many questions even; I just kept quiet and took notice" (James, 2011, p.82)

In chapter 6, Henry James (2011, pp. 77-78) frankly tells us about Isabel's flaws.

Sometimes she went so far as to wish that she might find herself some day in a difficult position, so that she should have the pleasure of being as heroic as the occasion demanded. Altogether, with her meagre knowledge, her inflated ideals, her confidence at once innocent and dogmatic, her temper at once exacting and indulgent, her mixture of curiosity and fastidiousness, of vivacity and indifference, her desire to look very well and to be if possible even better, her determination to see, to try, to know, her combination of the delicate, desultory, flame-like spirit and the eager and personal creature of conditions: she would be an easy victim of 
scientific criticism if she were not intended to awaken on the reader's part an impulse more tender and more purely expectant.

The objects reflected on the wall are of great importance as well. Considering Ralph as the fire, and everything else as the objects, Isabel's vision would be what is only reflected on the wall.

The two Misses Molyneux, this nobleman's sisters, came presently to call upon her, and Isabel took a fancy to the young ladies, who appeared to her to show a most original stamp. It is true that when she described them to her cousin by that term he declared that no epithet could be less applicable than this to the two Misses Molyneux, since there were fifty thousand young women in England who exactly resembled them (James, 2011, p.106).

Taking the two Misses Molyneux as an example of objects being reflected on the wall, Isabel sees them like the other fifty thousand young women who exactly resembled each other in England. Being quite different from Warburton's sisters, Isabel nevertheless, wishes she were like them.

'I think it's lovely to be so quiet and reasonable and satisfied. I should like to be like that.' 'Heaven forbid!' cried Ralph with ardour (James, 2011, p.107).

Objects, defined by Plato as puppets, include Madame Merle and Gilbert Osmond as well, both being the worst of all. We know Madame Merle has a dark side. It is not accidental that her name means a 'blackbird' in French which has a symbolic meaning. It is a bird:

[...] robed in black do not give up their secrets easily. They love to watch us marvel over their messages. Black birds demand our commitment to learning their wisdom, and do not reveal their meanings unless they are convinced we've devoted ourselves completely to the path of understanding (both dark and light sides of) energy (Symbolic Meanings of Black Birds, n.d.).

From her own utterances she foreshadows her true nature, but as mentioned, words are not sufficient for a truth seeker; we let Isabel experience everything by herself.

I try to remain in the cupboard-the quiet, dusky cupboard where there's an odour of stale spices-as much as I can. But when I've to come out and into a strong light-then, my dear, I'm a horror!' (James, 2011, p.247).

We also know the dark side of Osmond, who was first introduced by Madame Merle, who herself, later becomes a dark figure in Isabel's vision. On meeting Osmond, Isabel's first impression about his dwelling was striking enough to show its' graveness.

There was something grave and strong in the place; it looked somehow as if, once you were in, you would need an act of energy to get out (James, 2011, 318).

However, Isabel fails to see the reality again. The narrator's description is very revealing.

[...] this antique, solid, weather-worn, yet imposing front had a somewhat incommunicative character. It was the mask, not the face of the house. It had heavy lids, but no eyes; the house in reality looked another waylooked off behind, into splendid openness and the range of the afternoon light (James, 2011, pp. 287-288).

When the light of the sun shines on the freed man, he experiences enlightenment, says Plato. The minor concerns of the world as he has viewed them previously are now seen as falsely held perceptions. And this becomes the case with Isabel Archer as well;

Grave she found herself, and positively more weighted, as by the experience of the lapse of the year she had spent in seeing the world. She had ranged, she would have said, through space and surveyed much of 
mankind, and was therefore now, in her own eyes, a very different person from the frivolous young woman from Albany who had begun to take the measure of Europe on the lawn at Gardencourt a couple of years before. She flattered herself she had harvested wisdom and learned a great deal more of life than this lightminded creature had even suspected. If her thoughts just now had inclined themselves to retrospect, instead of fluttering their wings nervously about the present, they would have evoked a multitude of interesting pictures. These pictures would have been both landscapes and figure-pieces; the latter, however, would have been the more numerous. With several of the images that might have been projected on such a field we are already acquainted (James, 2011, p.399).

Descartes seems to echo Plato when he says 'why trust those who once deceived us, our senses deceive us yet we still believe everything we sense.' Plato used to state that our senses are deceiving us and we cannot always believe what we see and hear. He sees our lives as a 'puppet show' and we have not experienced true beauty because it is too vast for us to perceive it when we are trapped in the cave.

Once the prisoner is released, he is forced to look upon the fire and objects that once dictated his perception of reality, and he thus realizes these new images in front of him as the accepted forms of reality.

Plato describes the vision of the real truth to be "aching" to the eyes of the prisoners, and how they would naturally be inclined to go back and view what they have always seen as a pleasant and painless image of truth. This stage of thinking is noted as "belief." The comfort of the perceived, and the fear of the unrecognized outside world would result in the prisoner being forced to climb out of the cave and step outside into the bright sun. The same is the case when Isabel is getting slowly aware of the unexpected real visions that make her contemplate on 'reality';

[...] just beyond the threshold of the drawing-room she stopped short, the reason for her doing so being that she had received an impression. The impression had, in strictness, nothing unprecedented; but she felt it as something new, and the soundlessness of her step gave her time to take in the scene before she interrupted it. Madame Merle was there in her bonnet, and Gilbert Osmond was talking to her; for a minute they were unaware she had come in. Isabel had often seen that before, certainly; but what she had not seen, or at least had not noticed, was that their colloquy had for the moment converted itself into a sort of familiar silence, from which she instantly perceived that her entrance would startle them. Madame Merle was standing on the rug, a little way from the fire; Osmond was in a deep chair, leaning back and looking at her. Her head was erect, as usual, but her eyes were bent on his. What struck Isabel first was that he was sitting while Madame Merle stood; there was an anomaly in this that arrested her. Then she perceived that they had arrived at a desultory pause in their exchange of ideas and were musing, face to face, with the freedom of old friends who sometimes exchange ideas without uttering them. There was nothing to shock in this; they were old friends in fact. But the thing made an image, lasting only a moment, like a sudden flicker of light (James, 2011, p.506).

Once the prisoner climbs out of the cave, Socrates continues to explain the prisoner's bewilderment, fear, and blindness to the objects he was now being told were real (Schurk, N., 2006). The natural reaction of the prisoner would be to recognize shadows and reflections. After his eyes get used to the sunlight, he begins to see items and people in their own existence. When this has occurred, the ultimate stage of thought has been achieved, and that is 'understanding'.

Isabel is well aware of her living in the shadow of Osmond. She did her best to become a dutiful wife, but all her efforts were wasted on Osmond. Isabel's being intelligent annoys Osmond, because he had expected his wife to feel with him and for him.

She had taken all the first steps in the purest confidence, and then she had suddenly found the infinite vista of a multiplied life to be a dark, narrow alley with a dead wall at the end. Instead of leading to the high places of happiness, from which the world would seem to lie below one, so that one could look down with a sense of exaltation and advantage, and judge and choose and pity, it led rather downward and earthward, into realms of restriction and depression where the sound of other lives, easier and freer, was heard as from above, and where it served to deepen the feeling of failure. It was her deep distrust of her husband-this was what darkened the world. 
Then the shadows had begun to gather; it was as if Osmond deliberately, almost malignantly, had put the lights out one by one. The dusk at first was vague and thin, and she could still see her way in it. But it steadily deepened, and if now and again it had occasionally lifted there were certain corners of her prospect that were impenetrably black (James, 2011, pp. 526-527).

Plato then discusses the prisoner's newfound awareness of his own knowledge and understanding. Isabel, now understandingly questions herself, sees her mistakes, realizes that what she has been visioning all the way long was nothing but a reflection of a reflection;

But she had seen only half his nature then, as one saw the disk of the moon when it was partly masked by the shadow of the earth. She saw the full moon now-she saw the whole man (James, 2011, 528).

Upon returning to the Cave, the prisoner would metaphorically and literally enter a world of darkness yet again, and would be faced with the other unreleased prisoners. The other prisoners laugh at the released prisoner, and ridicule him for taking the useless ascent out of the cave in the first place. In Isabel's case, returning from her world tour to the so-called 'cave' she was

Between those four walls she had lived ever since; they were to surround her for the rest of her life. It was the house of darkness, the house of dumbness, the house of suffocation. Osmond's beautiful mind gave it neither light nor air; Osmond's beautiful mind indeed seemed to peep down from a small high window and mock at her. Of course it had not been physical suffering; for physical suffering there might have been a remedy (James, 2011, p.532)

The Allegory doesn't only represent our own misconceptions of reality, but also Plato's vision of what makes an independent and true character. The prisoner, through suffering, encounters Reality and the Divine Light. It took her naturally a long time to discover, and even then her discovery was imperfect (James, 2011, p.637). With the little touch of the people around her, Isabel finally escapes the cave. Countess Gemini helps her take the final step towards reality;

There's something I want you to know,' the Countess declared-"because I think you ought to know it. Perhaps you do; perhaps you've guessed it. But if you have, all I can say is that I understand still less why you shouldn't do as you like' (James, 2011, p.664).

'In the knowable realm,' says Socrates (Plato), 'the form of the good is the last thing to be seen, and it is reached only with difficulty.'(Cohen et al., 2005, p.514 a-b)

After Gemini's revelation, Isabel is free to act as she wants. Without thinking twice she goes to visit Pancy, after which she sets out for England to see Ralph. It is striking that she does not blame Madame Merle for her trapping 'That Madame Merle had lost her pluck and saw before her the phantom of exposure-this in itself was a revenge, this in itself was almost the promise of a brighter day' (James, 2011, p.677).

The last but not the least is the cave itself as a symbol in the novel. In his "How to Read Literature Like a Professor" Thomas C. Foster (2003) gives a number of symbolic meanings of the word 'cave'. According to him one of the meanings of the cave comes from Plato's 'Parable of the Cave': consciousness and perception. So, from this point of view we can say that Isabel's perception of the world is illusory. Isabel's 'active imagination' (James, 2011, 75) prevents her from listening to other people's advice. Henry James (2011, p.75) himself calls her 'presumptuous' in his preface to the novel.

The narrator is clear enough when he shares with us Isabel's flaws:

Altogether, with her meagre knowledge, her inflated ideals, her confidence at once innocent and dogmatic, her temper at once exacting and indulgent, her mixture of curiosity and fastidiousness, of vivacity and indifference, her desire to look very well and to be if possible even better, her determination to see, to try, to know, her 
combination of the delicate, desultory, flame-like spirit and the eager and personal creature of conditions: she would be an easy victim of scientific criticism if she were not intended to awaken on the reader's part an impulse more tender and more purely expectant (78) (James, 2011, 78).

Another meaning which Thomas C. Foster (2003) indicates is that the cave has or keeps secrets. In the light of this, we can consider Osmond himself as a caveman. We learn his secret from Countess only at the end of the book.

[...] 'In your place I should have guessed it ages ago. Have you never really suspected?'

'I've guessed nothing. What should I have suspected? I don't know what you mean.

'That's because you've such a beastly pure mind. I never saw a woman with such a pure mind!' cried the Countess.

[...] 'Ah, my good Isabel,' cried the Countess, 'with you one must dot one's i's!'

[...] She had spoken no name, yet Isabel could but check, on her own lips, an echo of the unspoken. She sank to her seat again, hanging her head (James, 2011, pp.664-672).

On the other hand, although he is a calculating and indolent man, Osmond is deceived in his expectations as regards Isabel. He thought he would be strong enough to subdue Isabel, but he failed.

We, all humans, go through the phase of understanding, and within this period we experience falsity, hypocrisy, mystery and several other delusory things. The Portrait of a Lady is a novel by Henry James that reflects the world of Isabel Archer in her quest for freedom and independency. She is misled by several pseudo-good looking people around her, but at last, like many of us, comes to realize the true reality of life. Similarly, the 'Allegory of the Cave' represented in Plato's 'The Republic' shows how people are to travel through their lives and understanding. The four stages of thought combined with the progress of human development represent our own path towards complete awareness which the most virtuous and distinguished will reach. It puts forward a splendid view on the way to reality which plays such an important part in our own existence, and in our understanding of it.

\section{References}

\section{Books}

Cohen, S.M., Curd, P., Reeve, C.D.C., Readings in Ancient Greek Philosophy From Thales to Aristotle, Hackett Publishing Company, 2005.

JAMES, H., The Portrait of a Lady. Harper Press, 2011.

Foster, T.C., How to Read Literature Like A Professor, Harper Perennial, 2003.

\section{Articles}

Hall, D., "Interpreting Plato's Cave as an Allegory of the Human Condition", Apeiron: A Journal for Ancient Philosophy and Science, Vol. 14, No. 2 (December 1980), pp. 74-86.

Sabiston, E., "The Prison of Womanhood", Comparative Literature, Vol. 25, No. 4 (Autumn, 1973), pp. 336-351.

Wright, J.H., "The Origin of Plato's Cave”, Harvard Studies in Classical Philology, Vol. 17 (1906), pp. 131-142.

\section{Internet Resources}

http://1.bp.blogspot.com/kU1aOyGDabs/UHt8E7juX7I/AAAAAAAAFYE/ZqY3OLCRP2w/s1600/plato1.jpg (Date Accessed: 03.12.12)

The Allegory of the Cave. (April 9, 2012). Retrieved Dec 12, 2012, from http://faculty.washington.edu/smcohen/320/cave.htm. 
Plato, The Allegory of the Cave. (May 13, 2004). In The History Guide. Retrieved Jan22, 2013, from http://www.historyguide.org/intellect/allegory.html.

What is the Allegory of the Cave?. (n.d.). In WiseGEEK. Retrieved Dec 10, 2012, from http://www.wisegeek.org/what-isthe-allegory-of-the-cave.htm.

Schurk, N. (Jul 10, 2006). Life in a Cave: The Flawed Philosophy of the Matrix. In Yahoo Voices. Retrieved Feb 2, 2013, from http://voices.yahoo.com/life-cave-flawed-philosophy-matrix-50760.html?cat=9.

Wikipedia Contributors. (April 22, 2012). The Destiny of Nations. In Wikipedia. Retrieved Feb 13, 2013, from http://en.wikipedia.org/w/index.php?title=The_Destiny_of_Nations\&oldid=488708075.

Symbolic Meanings of Black Birds. (n.d.) Retrieved February 10, 2013, from http://www.whats-your-sign.com/symbolicmeaning-of-blackbirds.html. 
